\title{
Issues in Border Security of Nepal
}

\author{
Yukesh Upreti \\ yuk.upreti@gmail.com
}

\begin{abstract}
Article History

Received September 28, 2020 Accepted November 10, 2020

Cross border is a major threat to the internal and external security of Nepal. To maintain peace and security and neutralize illicit trade, smuggling, and cross-border crimes, the Government of Nepal has deployed Security forces at the border. The Indo-Nepal border comparatively is challenging due to its open border status. This paper Keywords Border Security, Border Problems, Security Forces. analyses the field issues faced by security personnel at border areas of Nepal. The study uses both primary and secondary data for analysis and interpretation. The findings show geographical problems, socio-economic similarities, operational problems, border laws, values, and ethics. These issues are faced by security forces daily. The study outcome Corresponding Editor Ramesh Raj Kunwar kunwar.dr@gmail.com suggests a need for a collaborative approach of stakeholders on strengthening border security.
\end{abstract}

Copyright@2021 Author

Published by: APF Command and Staff College, Kathmandu, Nepal ISSN 2616-0242 


\section{Introduction}

'Border' has been a central part since the starting of the civilization of human beings, demarcation of the border for hunting, later on for cultivation, and so on are some examples. But the border got academic attention only in the late 90s. Brady (2014) "a loosely defined field of 'border studies' has been around since Frederick Jackson Turner (1893/1920) argued for the significance of the frontier and Herbert Eugene Bolton (1921) published The Spanish Borderlands: A Chronicle of Old Florida and the Southwest". Shrestha (2003) defined the concept of the border as "an independent nation has its own defined and demarcated boundaries, a permanent population, own strong and independent government and are also capable of conducting international relations beyond its borders". Shrestha further highlighted the importance of border with national security "for an independent country failing to protect its boundary is equal to failure in protecting its national security". Border Security in time of transformation (2010) has also explained the 'border' mixing with national security "The terrorist attack on 2011 transformed American and international conception of borders control as borders are viewed as a potential point of entry for world terrorists". Border security is always a critical issue that covers the multi-dimensional aspect of economic, social, cultural, and security. When borders are not regulated and protected the country plunges into a mess of conflict, crises, and smuggling that in the long run would lead to no less than a catastrophe. Different countries have adopted different systems of managing their borders. Nepal has a long history of its existence. Nepal has a controlled border system with China in its $1751 \mathrm{~km}$ length and an open border with India in 1414km (K.C., 2019). "The borders of Nepal have been unguarded and vacant for years. Quite inadequate efforts have been made by the center to develop infrastructure facilities to secure borders' ' (Jha, 2007). Additionally, K.C. focused on the geographical significance of the land of Nepal and focused on the feasibility of cross border crime that might affect the internal security of Nepal. Shrestha (2003) as well believed the open border with India has accounted for opportunities and threats to Nepal. Nepal and India both have established border security forces. Security forces aim to stop smuggling, prevent criminals from passing from the border, prevent the transaction of fake currency, prevent the girl from trafficking and prevent the flow of arms and ammunition (K.C.2019). Despite the deployment of security forces by both the countries, numbers of cross borders issues have been accounted for. Socio-economic, cultural, demographic, population, and religion are complex in the border areas. Sometimes, the inadequate policy measures, as well as the overlapping jurisdiction among security agencies, have created a vacuum in security delivery. In the end, all these variables have a direct relationship with the performance appraisal of security forces. Thus this study is closely focused on identifying the problems experienced by security forces in the border areas.

\section{Literature review}

A number of theories define the concept of territory. Kautilya's Saptang theory of the state has defined the seven elements of the state. The nature of Janapada defined in the Arthashastra indicates that both territory and population are intended to be covered by this 
expression (Kaur, 2010). Grotius(1615) as a Natural-law theorist has explained the concept of territory "human beings would be free to travel on it and engage in mutual exchange", consent theorist, John Locke (1689) defending the naturalist theorist argues "individuals can acquire property in land and other external material objects by 'mixing their labor' with it and thereby improving it" he then argued, "the difficulties that would be attendant on such an arrangement could only be solved by creating a jurisdictional authority to govern such people and protect their rights". Locke has highlighted the jurisdictional power required to govern that land with authority. Montevideo Convention on the Rights and Duties of States ( as cited in Grotenhuis, 2016) Article 1 reads: 'The state as a person of international law should possess the following qualifications: a) a permanent population; b) a defined territory; c) government; and d) capacity to enter into relations with the other states". The concept of territory in this convention is found to be the mix of Naturalist, Constant, Ethnographic, and Nationalist theories. This convention has established the relationship between the border concept and the responsibility of the state. He further highlighted the relationship of the state towards the people as a "rational contractor" to provide security, justice, and social service. It amplifies the duty of the state in securing the border of the state. Borders are the vulnerable points, it has a strategic concern. Some writers have defined the border as 'a source of terrorism and counterterrorism" (Carrol \& Gorawantschy, 2017), The ripple effect of terrorism as an "exchange of international problems" has been the center point of their definition.

The border security has been defined as an issue of National security with a major focus on territorial integrity, "Border management is a state primary responsibility as failure to protect its boundary is equal to failure in protecting national security" (Shrestha, 2003). "Border management seeks to secure the state first and then maintain interstate relations" (Bhardwaj,2012). Nepal shares a border with China and India. "Indo-Nepal border as an open and porous border which has both positive and negative implication" Shrestha (2003), Due to lack of education and poverty southern border of Nepal has been a fertile region for cross border crime "unemployment in youth in terai contributes to increment of crime" Tharda (2011). Reckless has characterized the border environment as "smuggling is the main character of Border" (1967). Nepal border has been facing crime, natural disasters, and bilateral issues with its bordering neighbors. Center for Strategic and International Studies (2010) has highlighted the necessity of "trained border police", "sufficient modern equipment" and "compatible bureaucratic relationship" for smooth and professional border security. Similarly, Harlon and Herbert (2019) have highlighted the causes of poor border security as "Weak presence of the state, the dearth of economic opportunity, and strong border ties among the local communities". In the Nepali context, these three major elements are lacking proper attention from the government side. The integration among government agencies is a crucial part of border management. The British and American experience has highlighted the importance of "information system integration to both operational and strategic border security success" (Coyne, 2015). Coyne further explained "screening at borders, document identification, information sharing" as a solution to fulfill the gap in border security information system integration. Harlon and Herbert, "Such environments have led to the development of illicit trade in the border zone". After the Mumbai attack in 2008, the recommendation of the group of ministers on 
reforming national security came out, and SSB was declared as a border guarding force. Whereas in Nepal, after peace talks between the government of Nepal and Maoist in 2005 Armed police force was declared as a border security force (Border Security in time of transformation, 2010).In spite of such deployment in borderlines, the numbers of crimes along the border have been reported. The actual reason behind the cause should be dug out, and there is a strong need for research to identify the problems of border security forces in the border area.

\section{Methodology}

The core objective of this research paper is to identify the field problems faced by security forces deployed in border areas of Nepal. For this purpose, the research followed a qualitative approach. The primary data is based on observation, interviews with security officers, and customs officers. Secondary data are collected from articles, published writings, books, online search engines.

\section{Border security scenario}

Every country in the world has established competent security forces for its internal and external security. In the context of Nepal, there are four security forces engaging in internal and external security. The army is responsible for external security unless assigned by the government of Nepal. Nepal Police, Armed Police Force, Nepal (APF), and National Investigation department are then engaged in internal security. Furthermore, the Armed Police Force is mandated with border security. The official deployments of APF in border areas come to the year 2063/12/27 BS. Before the deployment of APF, the Nepal army was deployed in the border area. With the ambition of controlling revenue leakage in the district of Terai and in order to protect border pillars, to safeguard the life of the people of the border, reduce trans-border crime, APF along with Nepal police have played a crucial role in border enforcement and revenue control. Despite the deployment of security forces in the borderline and tightening the regulation procedure at checkpoints, smuggling as well as the illegal cross border has increased (K.C., 2019).

Indo-Nepal frontier is open in nature which has been posed as a serious challenge due to the unregulated and undocumented movement of people. The border covers around 1800 $\mathrm{km}$ from east-south to west. Security personnel deployed at bordering states it's a most difficult task due to zigzag terrain, large swaths of land and marginal villages attached with no man's land on both sides. Due to zigzag and blended no man's land it is extremely difficult to nab fugitives and smugglers. Most probably they hide in villages across no man's land (Yadav, 2020).

The encroachment problems have not been solved and border people share feelings of insecurity. Security forces express dissatisfaction due to the problems they have been facing on the borders. These problems directly have a negative correlation with performance. The decrease in problem increases performance. 


\section{Deployment of security forces}

Deployment of security forces is the major indicator of border security. As one of the major principles of "Deterrence", the deployment of forces creates deterrence in the border and it grows confidence at the site. Armed Police Force Nepal is a specialized border security force of Nepal. Though Nepal Police is also deployed in the border area, their role is to support the Armed Police Force. Nepal Army has established border security directorates for the collection of information. The National Investigation Department is also playing a role in collecting, synthesizing and analyzing information related to national security along with border security. The total strength of SSB India is 94000 where 45000 personnel are deployed on Indo- Nepal border. Similarly, out of 37 thousand APF personnel of Nepal, 22000 are deployed in border areas comprising 59\% of the total strength that are dedicated to border security. Though the Government of Nepal has optimally deployed its forces, comparatively Nepal has deployed less number of forces in both Indian and Chinese border areas. Border security requires equipment, tools, and gadgets for screening, surveillance, identification, navigation, observation, and monitoring. The absence of these has caused lapses in security (Yadav, 2020). In Armed Police Force's report "Less human resources at the border, insufficient office infrastructure, lack of technological equipment, insufficient customs office" are regarded as the major challenges for border security. India has deployed a border patrol force (Seema Surakshya Bal) on entire Indo-Nepal borders establishing its post in about $3 \mathrm{Km}$ gap whereas APF has been able to establish its post in every 15-kilometer distance. The physical condition of barrack, equipment and information technologies are lacking in both APF and SSB. Both border guarding forces experience similar problems like border crimes, smuggling, and natural disasters and these problems either flow from India to Nepal or Nepal to India (Paudel, 2020).

\section{Socio-cultural similarities}

Most of the people residing in border areas share similar identities and social structures. The Indo-Nepal border has similar cultural and religious ties. Due to fewer population and settlement at the Nepal China border, the problem doesn't exist as compared to the indo-Nepal border. People sharing the same religion, culture, tradition, affinity is challenging in politically segregated areas. Security forces point out socio-cultural similarities as a catalytic factor for cross border crime. Due to similarity in cultural and religious tolerance and uniformity in mindset, people adopt to follow the same way of life. Most of the people at borderline are engaged in smuggling of goods and contraband, smuggling of narcotics, illegal transportation of arms, fake currency transportation which become the living pattern of their life. It has been difficult for security forces to nab these activities due to social protection which has spiked the crime rate. People from both sides are motivated due to easy learning and both countries' legal jurisdiction. Furthermore, Socio-culture also attracts violation of customs rules and regulations as people from Nepal purchase huge amounts of goods from India stating cultural and religious purposes like marriage, spiritual offerings, festivals, etc. Custom law only allows for purchasing goods for household purposes. Due to these problems Nepalese security forces have to face massive problems which resulted in discussion, quarrel and confrontation. Most people tend to violate custom law on socio-cultural grounds. 


\section{Border law}

Border law is a prerequisite to regulate open border situations between countries having open borders between them. Nepal sandwiched between two big giants China in the North and India in the South shares an open border with India. An open border is a threat to the peace and security of the nation importing criminal activities like money laundering, human trafficking, drug smuggling, and arms trafficking, etc, which culminates a vicious criminal cycle in the country. Despite the open border with India, Nepal does not have specific border laws to regulate and manage such border issues. It is using the mandates of the Armed Police Force (APF) and Nepal Police as a primary border security instrument. The Constitution of Nepal, 2072, and the National Security Policy of Nepal have paved the way towards foreign policy and diplomacy. They have proposed the Panchasheel principle as a directive to maintain the relation between the two countries. But still, there are not any specific ground rules to address border-related issues. Similarly, the overlapping responsibilities of APF and Nepal Police are imposing obstacles in the smooth functioning of border security.

\section{Operational problems}

Operation is the act of functioning or the fact of being active or in effect. The operations of SF at border areas are patrolling, securing border pillars, conducting a search of vehicles, surveillance, protecting and safeguarding the life of people and civic actions. Without the active participation of other stakeholders, operational success cannot be achieved. "SF faces lack of active cooperation, co-ordinations and assistance from local levels which reduces operational success|" (Yadav, 2020).

Due to lack of information sharing, lack of healthy relations, with other stakeholders like local government, local police, local governmental offices, and civil society, counterparts may bring a hindrance to the security system. There is a necessity for both covert and overt intelligence to achieve operational goals. An APF officer states, "We need to be dependent on others for intelligence for which we require additional budget". Information regarding illegal arms possession, drug smuggling, illicit trade, fake currency can only be achieved from covert intelligence (Paudel, 2020). Hence, operational problems raising security challenges are inadequate information sharing, lack of active intelligence agents, lack of cooperation, lack of societal support.

\section{Geography}

The terrain of Nepal is diverse consisting of Himalayan, Hilly, and Terai regions with 14, 68, and 15 percent of the total area respectively. Nepal shares its international border in all diverse geographical locations. It is one of the unique terrains of the world which have geographical differences from $60 \mathrm{~m}$ to $8848 \mathrm{~m}$ from sea level. The high Himalayan demarks Nepal- China boundary and it is declared as a demilitarized zone that covers $20 \mathrm{~km}$ inside from boundary by Nepal-China boundary treaty of 21 March 1960 (Shrestha, 2003). It is one of the peaceful and regulated borders with very few security posts. "Due to its high 
altitude, the government of Nepal has not been able to establish adequate checkpoints. There are only 6 Border outposts in Nepal- China frontier. The high altitude, rugged terrains are the major problems faced by security personnel in this region. Also, transporting necessary logistics and equipment is costly as airlift is required. There is no man-made boundary demarcation on land as indicated in the boundary treaties except for boundary pillars" (Kansakar, 2000). The geographical feature at the border area has encouraged people to crime which is a huge problem for SF to deter.

\section{Ecology}

The border area of Nepal ranges from $60 \mathrm{~m}$ datum level to $8848 \mathrm{~m}$ high altitude. Nepal- China border area lies in high altitude so due to extreme cold temperature only a few border security posts. Some of the posts needed to be shifted to low altitudes during winter seasons due to a massive temperature below -15 degrees Celsius or more. However, the government of Nepal has added 2 new security posts in Darchula district due to border dispute and has planned to add 6 APF posts in the northern border. SF states lack the necessary apparatus to adopt in cold temperatures. However, in the Indo-Nepal border area, there are 119 security posts to date and the weather is considered to be evergreen. Temperatures range 15-20 degrees Celsius in the winter season and rise up to 50 degrees Celsius in summer seasons. "Due to flood, No Man's land is inundated, extreme cold at the cold season and extremely hot at summer seasons are ecological problems faced by SF in border-deployment" (Paudel, 2020).

\section{Values and ethics}

Smuggling is one of the major problems in most of the borders of the world. Somehow, Smuggling has been a means of additional warning to border enforcement agencies. Nepalese security forces at the frontier are also alleged with corruption, bribe, and nexus with smugglers. Smuggling has become the profession of the bordering population.

\section{Others problems}

Field visits and direct interviews with security personnel brought up different problems faced by SF in their day-to-day operation. Open borders and a homogenous society have been a prime challenge. Growing Nepalese dependency on the Indian market and fewer customs offices in the borderline are independent factors of SF problems. People choose cheap commodities and due to the high tax rate in Nepal, people choose to purchase from India. An APF constable deployed in Raxaul, Indo-Nepal border state, it is difficult to stop all pedestrians who have consumed goods from the Indian market. The Custom Act clearly mentions tax-free for house appliances and nominal goods. Due to this provision, the Indian big market near the Indo-Nepal border is a major shopping zone for Nepalese people. Besides this, SF faces threat, physical attacks from smugglers, and tuskers. In the year 2020, Due to the corona virus outbreak, both countries impose a border restriction to curb the virus. As a result, in more than 17 places many Indian people demanded to get entry to Nepal and physically attacked APF men and vandalize duty posts which resulted 
in a confrontation. The following are other problems faced by SF in border deployment.

- $\quad$ Attack from Indian smugglers.

- Unnecessary debate and clash with Nepalese citizens.

- The baseless allegation to SF. (Demoralization).

- $\quad$ Encroachment Issue.

- Stagnation and enmity.

- Low morale and motivating factors.

- Lack of proper intelligence.

\section{Conclusion}

Borders of the world are compared to be porous and fertile for illicit trade, smuggling and organized crime. Nepal, Located between two economically and politically powerful nations, India and China are vulnerable to cross-border crime which has weakened national security. In order to keep peace, security, and prosperity in Nepal, the security forces of the nation must be strengthened. Understaffed, insufficient resources, lack of morale and motivation, incentives and unclear plan and policy are a hindrance for border security in Nepal. The government of Nepal needs to take necessary steps in the proliferation of border security which require policy formation, diplomatic collaborative plans, technological adaptation, operational cooperation, human resources inventory, collaborative engagement, and institutional reforms. All the concerned authorities should realize the need for investment in security as par with international standards. Now it is time to improve Security forces capacity by empowering necessary infrastructure, training, and resources.

The practice of compensation and reward management, incorporating ethics and values, and adapting the technology apparatus should be institutionalized. The catalyst factors like poverty, unemployment, population growth, technological advancement, and capital market are encouraging border crimes. Security forces of the country should be more active and courageous to deter border crimes by producing skilled manpower and the formation of adequate policy. The multi-sector engagement with concerned stakeholders needs to have cooperated for better management. Furthermore, to achieve deep insight into the subject matter further research needs to be done.

\section{References}

Brady, M. (2014). Border. In Burgett, B. \& Hendler, G. (Eds.), Keywords for American Cultural Studies, Second Edition.

Carrol, J., \& Gorawantschy, B. (2017). ASPI-KAS: 2nd Australia-Europe Counter-Terrorism Dialogue 3-4 November 2016, Canberra (pp. 15-16, Rep.). ustralian Strategic Policy Institute. Retrieved July 19, 2020, from www.jstor.org/ stable/resrep04251.10

Center for Strategic and International Studies. (2010). Border Security in Time of Transformation. 
Coyne, J. (2015). Securing the Australian frontier: An agenda for border security policy (pp. 15-18, Rep.). Australian Strategic Policy Institute. Retrieved July 21, 2020, from www.jstor.org/stable/resrep04218.7

Bhardwaj, V. (2009), Indo-Nepal open international border: challenges and management. Himalayan journal of Development and Democracy. Vol. 4.No 1.

Brady, M. (2014). Border. In Burgett B. \& Hendler G. (Eds.), Keywords for American Cultural Studies, Second Edition (pp. 34-37). NYU Press. Retrieved November 3, 2020, from http://www.jstor.org/stable/j.ctt1287j69.11

Grotenhuis, R. (2016). Nation and state. In Nation-Building as Necessary Effort in the Fragile States (pp. 25-44). Amsterdam: Amsterdam University Press. doi:10.2307/j.ctt1gr7d8r.5

Grotius, Hugo, c. 1615 [2004], "Defense of Chapter V of the Mare Liberum", Reprinted in The Free Sea, David Armitage (ed.), Herbert F. Wright (trans.), Natural Law and Enlightenment Classics, Indianapolis, IN: Liberty Funds, pp. 75-130. [Grotius 1615 [2004] available online]

Harlon,Q. \& Herbert, M. (2019). Border security challenges in grand Maghreb. Retrieved from https://www.files.ethz.ch/isn/191018/PW109-Border-Security-Challengesin-the-Grand-Maghreb.pdf

Indian border security, Poor management evidence. (2015). Institute of peace and conflict studies.

Jha, H. (2007). Nepal's border relations with India and china. Retrieved from $h t t p: / / s r c-h$. slav.hokudai.ac.jp/publictn/eurasia_border_review/Vol41/V4N104J.pdf

K.C., D. (2019). Cross border crime and its security concerns in Nepal. Journal of APF command and staff college. Volume 2, Issue 1.

Kansakar, V. (2000). Nepal India open border: Prospects, Problems and challenges.

Kaur, K. (2010). KAUTILYA : SAPTANGA THEORY OF STATE. The Indian Journal of Political Science, 71(1), 59-68. Retrieved July 26, 2020, from www.jstor.org/ stable/42748368

Locke, John, 1689 [1988], John Locke: Two Treatises of Government, Peter Laslett (ed.), Cambridge: Cambridge University Press. doi:10.1017/CBO9780511810268

Paudel, R. (2020, 3 24). Difficulties faced by SF in the border line. (Y. Upreti, Interviewer)

Shrestha, B. (2003). Border management of Nepal. In B. n. Shrestha. AIMSA Collection for studies.

Tharda (2011). (Terai human rights Defenders alliances). (2011, July) . Small arms terror in Central Madhes. Report July 2011.

Yadav, K. (2020, 3 24). Problems faced during border security. (Y. Upreti, Interviewer) 